\title{
Energy balance with Landsat images in irrigated central pivots with corn crop in the São Paulo State, Brazil
}

\author{
Antônio H. de C. Teixeira ${ }^{*}$, Fernando B. T. Hernandez ${ }^{\mathrm{b}}$, Ricardo G. Andrade ${ }^{\mathrm{a}}$, Janice F. Leivas ${ }^{\mathrm{a}}$, \\ Edson L. Bolfe ${ }^{\mathrm{a}}$ \\ ${ }^{a}$ Embrapa Satellite Monitoring, Campinas, São Paulo, Brazil; ${ }^{b}$ São Paulo State University, Ilha \\ Solteira, São Paulo, Brazil.
}

\begin{abstract}
The energy balance (EB) components were quantified in a commercial farm with corn crop, irrigated by central pivots, in the Northwestern side of São Paulo state, Southeast Brazil. The SAFER (Simple Algorithm For Evapotranspiration Retrieving) was applied to retrieve the latent heat flux $(\lambda \mathrm{E})$, considering six pivots, covering irrigated areas from 74 to 108 ha. With $\lambda$ E quantified and considering soil heat flux $(\mathrm{G})$ as a fraction of net radiation $\left(\mathrm{R}_{\mathrm{n}}\right)$, the sensible heat flux $(\mathrm{H})$ was acquired as a residual in the energy balance equation. Seven Landsat satellite images, covering all corn crop stages from 23 April 2010 to 29 August 2010, allowed relating the energy balance components according to the accumulated degree-days $\left(D_{\mathrm{ac}}\right)$ from the planting to harvest dates. The average $R_{n}$ values ranging from 5.2 to $7.2 \mathrm{MJ} \mathrm{m}^{-2}$ day $^{-1}$, represented 30 to $45 \%$ of global solar radiation $\left(\mathrm{R}_{\mathrm{G}}\right)$. Considering the variation of the energy balance components along the corn crop growing seasons, the average ranges for $\lambda \mathrm{E}, \mathrm{H}$ and $\mathrm{G}$ were respectively 0.0 to $6.4 \mathrm{MJ} \mathrm{m}^{-2}$ day ${ }^{-1},-1.5$ to 6.7 $\mathrm{MJ} \mathrm{m}^{-2}$ day $^{-1}$ and 0.1 to $0.6 \mathrm{MJ} \mathrm{m}^{-2}$ day $^{-1}$. The fraction of the available energy $\left(\mathrm{R}_{\mathrm{n}}-\mathrm{G}\right)$ used as $\lambda \mathrm{E}$ was from 0.0 to 1.3 indicated a good irrigation management, insuring that the water deficit could not be the reason of any yield reduction. Although $R_{n}$ did not reflected well the crop stages, its partition strongly depended on these stages. $\lambda E$ higher than $R_{n}$ and the negative $H / R_{n}$, happened sometimes along the corn growing seasons. This occurred after the vegetative growth and before the harvest times, indicating heat advection from the surrounding areas to the irrigation pivots, which represented an additional energy source for the evaporative process. The models applied here with only the visible and infrared bands of the Landsat sensor are very useful for the energy balance analyses, considering the size of the corn crop irrigation pivots in Southeast Brazil, when subsidizing a rational irrigation water application in corn crop.
\end{abstract}

Keywords: net radiation, latent heat flux, sensible heat flux, soil heat flux.

\section{INTRODUCTION}

In the Southeast region of Brazil, one of the main crops is corn (Zea mays L.), which has been cultivated in two periods of the year for human consumption or/and animal feed. Considering the first period (first-harvest crop), the sowing time is between October and November, coinciding with the start of rains, while for the second period (second-harvest crop), the sowing times are from February to March.

Soil moisture is important for maintaining yield at optimum levels, being the natural water deficit (WD) the main risk factor for the second-harvest corn crop, which, when considering rainfed conditions, this problem can be attenuated at high altitudes [1]. Water stress can affect the plant development and the physiological processes, reducing yield, which in turn is a linear function of latent heat flux $-\lambda \mathrm{E}[2,3]$.

" heriberto.teixeira@embrapa.br; Phone 55 19 3211-6200; Fax: 55 19 3211-6222; www.cnpm.embrapa.br

Remote Sensing for Agriculture, Ecosystems, and Hydrology XVI, edited

by Christopher M. U. Neale, Antonino Maltese, Proc. of SPIE Vol. 9239, 923900

(C) 2014 SPIE · CCC code: $0277-786 X / 14 / \$ 18 \cdot$ doi: $10.1117 / 12.2067090$

Proc. of SPIE Vol. $9239923900-1$ 
Having in mind water scarcity scenarios in São Paulo, analyses of the energy balance components in commercial farms for grains are relevant in case of water competition with other sectors rather than agriculture, especially in the Northwestern side of the state. On the other hand, high probabilities of natural water scarcity during the crop growing seasons arise, making irrigation an essential practice for good yields [4].

Considering the simplicity of application and the absence of neither the need of vegetation classification nor identification of extreme hydrological conditions, in the current study, the SAFER (Simple Algorithm For Evapotranspiration Retrieving) model was applied to estimate $\lambda \mathrm{E}$, while to take into account the crop stages the accumulated degree-days $\left(\mathrm{DD}_{\mathrm{ac}}\right)$ was used. SAFER model was developed and validated with field measurements involving irrigated crops and natural vegetation in the semi-arid environment of Brazil. The Slob equation was used to retrieve the net radiation $\left(R_{n}\right)$, soil heat flux was considered as a fraction of $R_{n}$ and the sensible heat flux $(H)$ was estimated by residual in the energy balance equation [5]

The objective of the current research was to apply energy balance models together with Landsat images and a weather station for quantification of the components of this balance along the growing season a corn crop, irrigated by central pivots, for commercial grains. The pivots are located in the Bonança farm, at the Northwestern side of the São Paulo state, Brazil. The analyses can subsidize a rational water management of corn, as this is one of the most important agricultural crop inside the priorities of the Agricultural Brazilian Ministry.

\section{MATERIAL AND METHODS}

Figure 1 shows the locations of the irrigation central pivots at the commercial Bonança farm and the agrometeorological station used in the Northwestern side of São Paulo (SP) state, Southeast Brazil.

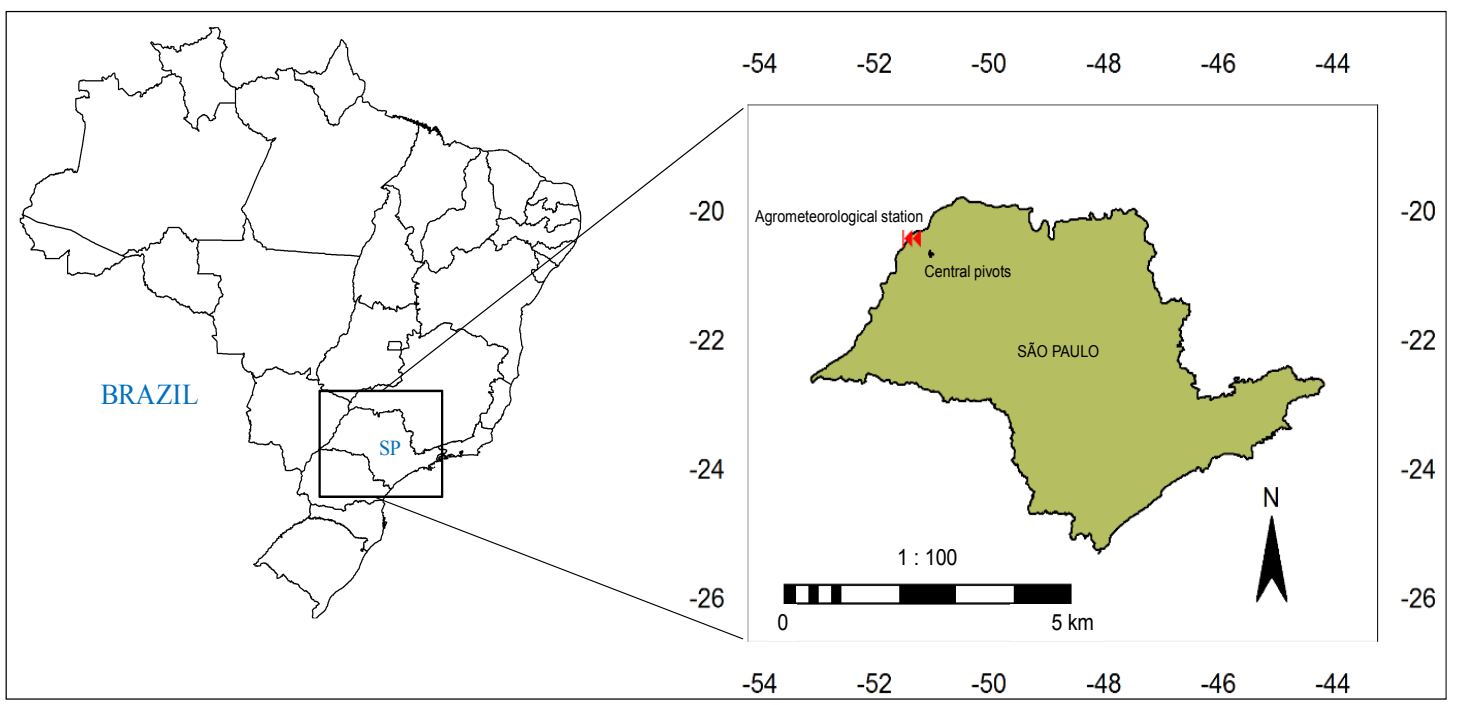

Figure 1. Location of the irrigation central pivots over corn crop at the Bonança farm, together with the agrometeorological station used in the Northwestern side of São Paulo (SP) state, Southeast Brazil.

This area is characterized by dry winter and a moderate and wet summer, presenting the highest evapotranspiration rates of the state. Some periods with absence of rains may limit productivity without irrigation due to the natural water deficits, which can occur at durations as long as eight months [6].

The SAFER algorithm was applied to 7 Landsat satellite images from March 22, April 07, April 23, June 10, June 26, July 12 and August 29 of 2010. The energy balance components were acquired, by using only the visible and near infrared bands together with agrometeorological data, being the surface temperature $\left(T_{0}\right)$ estimated from the long-wave 
emitted radiation as a residual in the radiation balance. This was done to bring all the results for irrigation pivots to a spatial resolution of $30 \mathrm{~m}$, avoiding the spatial resolution of $120 \mathrm{~m}$ from the Landsat 5 thermal band. Agrometeorological data for 2010 were used together with these images and the energy balance components were related to a generalized corn crop growing season by relating it to the accumulated degree-days $\left(\mathrm{DD}_{\mathrm{ac}}\right)$, considering a basal temperature of $10^{\circ} \mathrm{C}[7]$.

The planetary albedo for each satellite band $\left(\alpha_{p_{\text {band }}}\right)$ was calculated as:

$$
\alpha_{\mathrm{p}_{\text {band }}}=\frac{\mathrm{L}_{\text {band }} \pi \mathrm{d}^{2}}{\mathrm{R}_{\mathrm{a}_{\text {band }}} \cos \varphi}
$$

where $\mathrm{L}_{\text {band }}$ is the spectral radiance for the wavelengths of the band, $d$ is the relative earth-sun distance; $R_{a_{\text {band }}}$ is the mean solar irradiance at the top of the atmosphere for each band $\left(\mathrm{Wm}^{-2} \mu \mathrm{m}^{-1}\right)$ and $\varphi$ the solar zenith angle.

The planetary albedo for the whole solar spectrum $\left(\alpha_{\mathrm{p}}\right)$ was calculated as the total sum of the different narrow-band $\alpha_{p_{\text {band }}}$ values according to weights for each band ( $\left.\mathrm{w}_{\text {band }}\right)$.

$$
\alpha_{\mathrm{p}}=\sum \mathrm{w}_{\mathrm{band}} \alpha_{\mathrm{p}_{\text {band }}}
$$

The weights for the different bands are computed as the ratio of the amount of the incoming shortwave radiation from the sun in a particular band and the sum of incoming shortwave radiation for all the bands at the top of the atmosphere.

The daily values of surface albedo $\left(\alpha_{0}\right)$ were calculated according to [5]:

$$
\alpha_{0}=a \alpha_{p}+b
$$

where a and b are regression coefficients, which for a 24 hour period were respectively 1.70 e 0.13 .

The Normalized Difference Vegetation Index (NDVI) is a key indicator related to the land cover obtained from satellite images as:

$$
\mathrm{NDVI}=\frac{\alpha_{\mathrm{p}_{(\mathrm{NIR})}}-\alpha_{\mathrm{p}_{(\mathrm{RED})}}}{\alpha_{\mathrm{p}_{(\mathrm{NIR})}}+\alpha_{\mathrm{p}_{(\mathrm{RED})}}}
$$

where $\alpha_{\mathrm{p}_{(\mathrm{NIR})}}$ and $\alpha_{\mathrm{p}_{(\mathrm{RED})}}$ represent the planetary albedo over the ranges of wavelengths in the near infrared (NIR) and red (RED) regions of the solar spectrum, respectively [5].

Instead of using the thermal band from Landsat $5(120 \mathrm{~m}), \mathrm{T}_{0}$ in the current study was estimated with only the red and infrared bands (spatial resolution of $30 \mathrm{~m}$ ) as a residual in the radiation balance equation:

$$
\mathrm{T}_{0}=\sqrt[4]{\frac{\mathrm{R}_{\mathrm{G}}-\alpha_{0} \mathrm{R}_{\mathrm{G}}+\varepsilon_{\mathrm{a}} \sigma \mathrm{T}_{\mathrm{a}}^{4}-\mathrm{R}_{\mathrm{n}}}{\varepsilon_{0} \sigma}}
$$

where $R_{G}$ and $T_{a}$ are respectively the daily values of the incident solar radiation and mean air temperature at the agrometeorological station; $R_{n}$ is the daily net radiation; $\varepsilon_{\mathrm{a}}$ and $\varepsilon_{0}$ are respectively the atmospheric and surface emissivities; and $\sigma$ is the Stefan-Boltzmann constant $\left(5.67 \times 10^{-8} \mathrm{~W} \mathrm{~m}^{-2} \mathrm{~K}^{-4}\right)$. 
$\varepsilon_{\mathrm{a}}$ and $\varepsilon_{0}$ were calculated as following [5]:

$$
\begin{aligned}
& \varepsilon_{\mathrm{a}}=\mathrm{a}_{\mathrm{a}}\left(-\ln \tau_{\mathrm{s}}\right)^{\mathrm{b}_{\mathrm{a}}} \\
& \varepsilon_{0}=\mathrm{a}_{0} \ln \mathrm{NDVI}+\mathrm{b}_{0}
\end{aligned}
$$

where $\tau_{\mathrm{s}}$ is the short-wave transmissivity calculated as the ratio of $\mathrm{R}_{\mathrm{G}}$ to the incident solar radiation at the top of the atmospheric; and $\mathrm{a}_{\mathrm{a}}, \mathrm{b}_{\mathrm{a}}, \mathrm{a}_{0}$ and $\mathrm{b}_{0}$, are regression coefficients taking as $0.94,0.10,0.06$ and 1.00.

Daily $R_{n}$ can be described by the 24-hour values of net shortwave radiation, with a correction term for net longwave radiation for the same time-scale [8]:

$$
\mathrm{R}_{\mathrm{n}}=\left(1-\alpha_{0}\right) \mathrm{R}_{\mathrm{G}}-\mathrm{a}_{1} \tau_{\mathrm{sw}}
$$

where $a_{1}$ is the regression coefficient of the relationship between net long wave radiation and atmospheric shortwave transmissivity $\left(\tau_{\mathrm{sw}}\right)$ at the daily scale.

Because of the thermal influence on longwave radiation via the Stephan Boltzmann equation, previous study investigated whether the variations of the $a_{1}$ coefficient from Eq. 8 could be explained by variations in 24 hours $T_{a}$ [8]:

$$
\mathrm{a}_{1}=\mathrm{cT}_{\mathrm{a}}-\mathrm{d}
$$

where $\mathrm{c}$ and $\mathrm{d}$ are regression coefficients found to be 6.99 and 39.93, respectively for the Brazilian Northeast conditions.

Eq. 8 was derived by [8] considering four energy balance field experiments involving different thermohydrological conditions in Brazil. This was first done because in several remote sensing energy balance models it is used for extrapolation instantaneous to daily values of $R_{n}$. In the current study this by applying Eq. $8, R_{n}$ is calculated for every pixel from $\alpha_{0}$, which in turn comes from $\alpha_{\mathrm{p}}, \mathrm{R}_{\mathrm{G}}$, and $\tau_{\mathrm{sw}}$ that is calculated by the ratio of $\mathrm{R}_{\mathrm{G}}$ to the solar radiation at the top of the atmosphere, which is variable according to the zenithal angle. In addition, the $a_{1}$ coefficient (Eq. 9) is also correlated with air temperature $\left(\mathrm{T}_{\mathrm{a}}\right)$, instead of using the original constant value. Other advantage of using Eq. 9 is the possibility of application in any environment according to the thermal conditions, with the only probability of adjusts of the regression coefficient.

For the daily $G$ values, the equation derived by [9] is used:

$$
\frac{G}{R_{n}}=\operatorname{eexp}\left(f \alpha_{0}\right)
$$

where e and $\mathrm{f}$ are regression coefficients found to be 3.98 and -25.47 , respectively for the Brazilian semi-arid conditions. With the images of $\alpha_{0}, T_{0}$ and and NDVI, ET was obtained by the SAFER algorithm [5].

$$
\frac{\mathrm{ET}}{\mathrm{ET}_{0}}=\exp \left[\mathrm{g}+\mathrm{h}\left(\frac{\mathrm{T}_{0}}{\alpha_{0} \mathrm{NDVI}}\right)\right]
$$


where $\mathrm{ET}$ and $\mathrm{ET}_{0}$ are respectively the actual and reference evapotranspiration. $\mathrm{ET}_{0}$ is calculated with data from the agrometeorological station (see Figure 1) by the Penman-Monteith method [10] and $\mathrm{g}$ and $\mathrm{h}$ are regressions coefficients, which for the Brazilian semiarid conditions were 1.8 and - 0.008 , respectively.

Transforming ET into energy units, the 24-hour values of latent heat flux $(\lambda \mathrm{E})$ were obtained, and then the sensible heat flux $(\mathrm{H})$ estimated as the residual in the energy balance for the same time-scale:

$$
\mathrm{H}=\mathrm{R}_{\mathrm{n}}-\lambda \mathrm{E}-\mathrm{G}
$$

The evaporative fraction $\left(\mathrm{E}_{\mathrm{f}}\right)$ was applied to take into account the soil moisture conditions:

$$
E_{f}=\frac{\lambda E}{R_{n}-G}
$$

\section{RESULTS AND DISCUSSION}

As the energy partition depends on the thermohydrological conditions, the monthly behaviour of the totals of precipitation $(\mathrm{P})$ and the daily average values of $\mathrm{R}_{\mathrm{G}}$ along the year 2010 is shown in Figure 2. Agrometeorological data from the weather station located in Norhtwestern side São Paulo (SP) state, Southeast of Brazil (see Figure 1), were used.

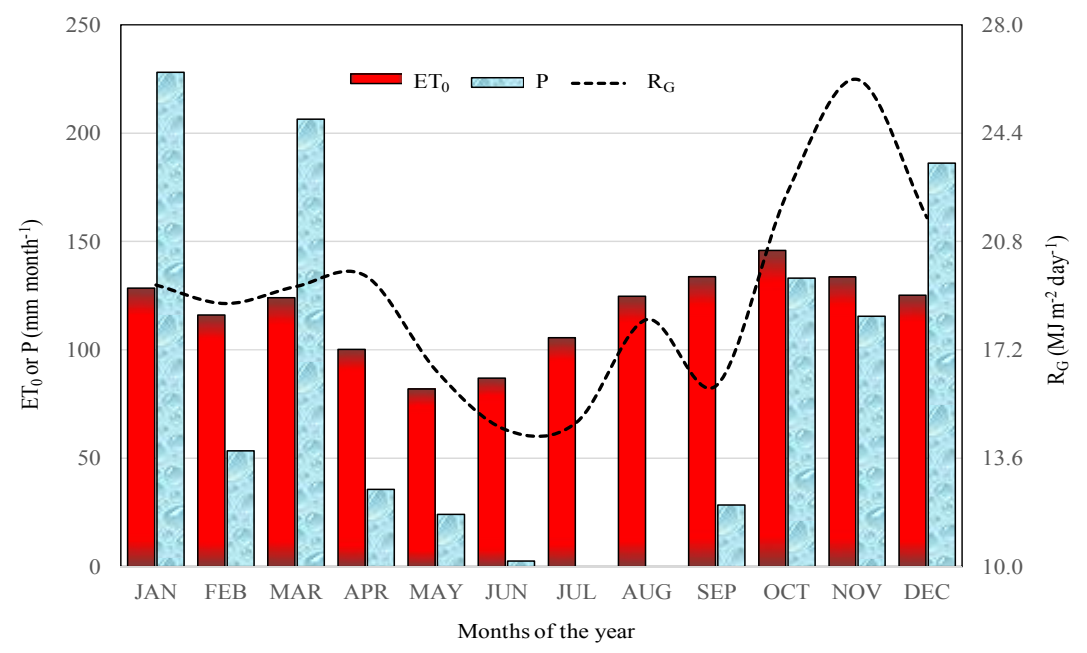

Figure 2. Monthly total values of reference evapotranspiration $\left(\mathrm{ET}_{0}\right)$ and precipitation $(\mathrm{P})$, together with the monthly average daily values for global solar radiation $\left(\mathrm{R}_{\mathrm{G}}\right)$ at the agrometeorological station, during the year of 2010 in the Northwestern side of São Paulo State, Southeast Brazil.

$R_{G}$ represents the main energy source for the $\lambda \mathrm{E}$. During 2010, its values were lower from May to September, around 16.2 $\mathrm{MJ} \mathrm{m}^{-2}$ day $^{-1}$, at the winter solstice in the South hemisphere, and higher from October to December, averaging 23.4 MJ m ${ }^{-2}$ day $^{-1}$, when the sun is near the zenith position with low cloud cover. Large $R_{\mathrm{G}}$ contributes to strong atmosphere demand. Although the largest $\mathrm{ET}_{0}$ values occurring at the start and at the end of 2010, reaching monthly total values higher than $145 \mathrm{~mm} \mathrm{month}^{-1}$ in October, the variations along the year is not so strong when comparing with the corresponding ones for $\mathrm{P}$. The only months with $\mathrm{ET}_{0}$ lower than $100 \mathrm{~mm} \mathrm{month}^{-1}$ were May and June. Considering P as the natural input in the water balance, much more monthly variation is verified.

Taking the difference between $\mathrm{P}$ and $\mathrm{ET}_{0}$ as a crude measure of the natural water availability, in 2010 there were climatic water excesses (P > ET0) only during the months of January $(100 \mathrm{~mm})$, March $(82 \mathrm{~mm})$ and December $(61 \mathrm{~mm})$, while climatic water deficit $(\mathrm{P}-\mathrm{ET} 0<0)$ reached to $125 \mathrm{~mm} \mathrm{month}^{-1}$ from July to September. According to the corn crop 
stages, concentrated from March to August, the need of irrigation is evident, which should be based on the energy balance partition.

Figure 3 presents the model remote sensing input parameters obtained from the combination of Landsat and agrometeorological measurements, related to vegetation and soil moisture conditions, and then to the energy balance. These measurements involved different corn crop stages, in the corn irrigation pivots, along the growing seasons inside the commercial Bonança farm, Northwestern side of São Paulo State, Southeast Brazil.

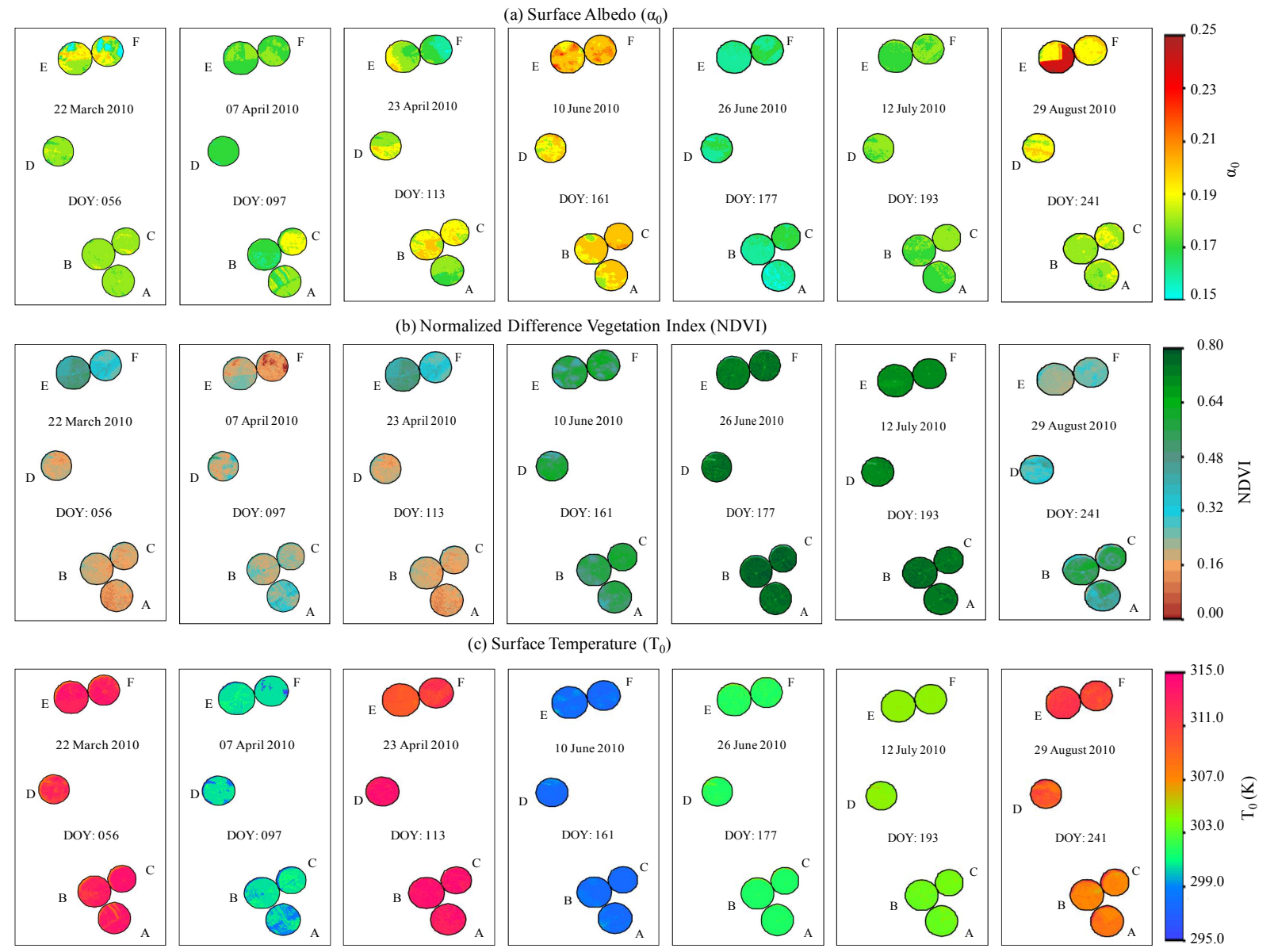

Figure 3. Spatial distribution of the remote sensing model input remote sensing parameters in the commercial Bonança farm, Northwestern side of São Paulo state, Southeast Brazil, for each day of the year (DOY), involving different thermohydrological conditions of the corn crop growing seasons. (a) surface albedo $\left(\alpha_{0}\right)$; (b) Normalized Difference Vegetation Index (NDVI); and surface temperature $\left(\mathrm{T}_{0}\right)$.

The highest $\alpha_{0}$ values, larger than 0.20 in several pixels, were observed in 10 June 2010 (DOY 161), while the lowest ones happened in 12 July 2010 (DOY 193) (Figure 3a). The $\alpha_{0}$ values were strongly dependent on the corn crop stages and on the soil moisture conditions $[8,11,12]$. The differentiation of the NDVI values among the pivots and along the year (Figure 3b) is also evident, with the largest ones occurring from June (DOY 161) to July (DOY 193), when the crop was in the transition stage of blooming to grain filling in general, with values above 0.70 in the pivots $\mathrm{A}, \mathrm{B}$ and $\mathrm{C}$ in the majority of the pixels. On the other hand, the lowest ones were at the start of the growing seasons, from February to April (DOY 066 to 113). $\mathrm{T}_{0}$ affects the available energy, interfering in the long wave radiation balance. In general, with exception of the image for 07 April 2010, after a period of high levels of precipitation (see Figure 2), its highest values coincided with those with the largest $R_{G}$ levels (see Figures 2 and $3 \mathrm{c}$ ) and the lowest ones happened in the middle of the year (DOY 161-193), under the conditions of uniform soil moisture in the root zones for corn crop and low $\mathrm{R}_{\mathrm{G}}$. The 
variability of $\alpha_{0}$, NDVI, and $T_{0}$ in irrigated corn crop can be mainly attributed to variation in $\mathrm{R}_{\mathrm{G}}$ and soil moisture conditions due to rainfall and irrigation.

Figure 4 shows the spatial distribution of $\mathrm{R}_{\mathrm{n}}$ daily values for different periods of the corn crop growing seasons during 2010, in central irrigation pivots with corn crops, at the Bonança commercial farm, Northwestern side of São Paulo State, Southeast Brazil.

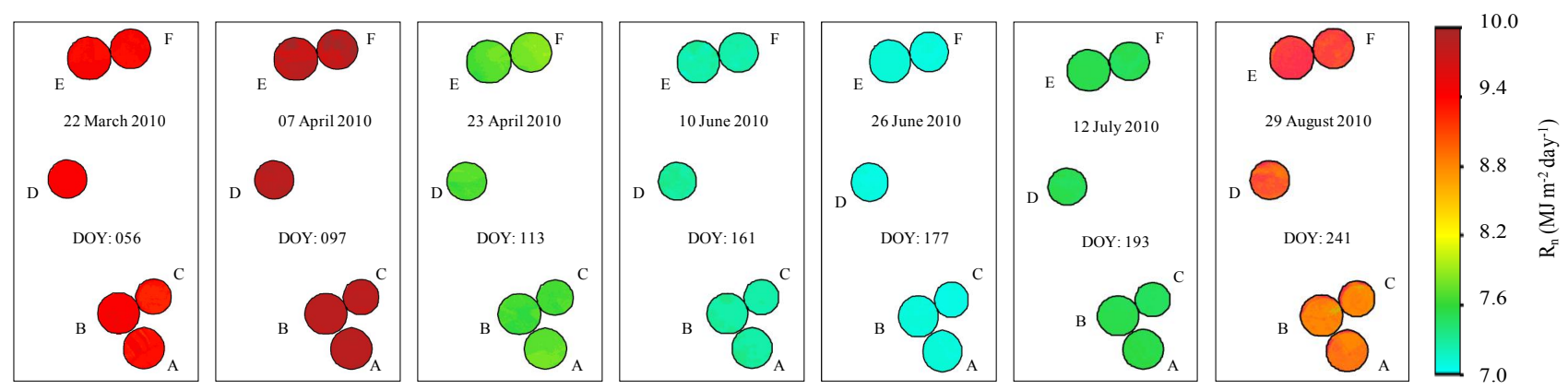

Figure 4. Spatial distribution of the net radiation $\left(R_{n}\right)$ daily values in corn crop irrigation pivots of the Bonança farm, Northwestern side of São Paulo state, Southeast of Brazil, for each day of the year (DOY), involving different thermohydrological conditions of the growing seasons.

In general, $R_{n}$ values were closely related to $R_{G}$ levels, with no big spatial variation inside the irrigation pivots, independently of the corn crop stages and soil moisture conditions (see Figures 2 and 4 ). However, the highest $R_{n}$ levels in 07 April 2010 may be attributed to large levels of soil moisture from the previous precipitation with simultaneous $R_{G}$ increases (see Figure 2). This high soil moisture lowered both $\alpha_{0}$ and $\mathrm{T}_{0}$, and then reduced the reflected and emitted short and long radiation from the cropped surface. In this last occasion, the $\mathrm{R}_{\mathrm{n}}$ values were close to $10.0 \mathrm{MJ} \mathrm{m}^{-2}$ day $^{-1}$. On the other hand, under low $R_{G}$ levels, as represented by the image of 26 June 2010 (DOY 177), $R_{n}$ values are as low as 7.0 $\mathrm{MJ} \mathrm{m}^{-2}$ day $^{-1}$, increasing again in August (DOY: 241), at the start of spring in the South hemisphere.

As it is difficult to analyse the effect of the corn crop stages and soil moisture based only on $R_{n}$, it is important to quantify its partition into the different energy fluxes. Figure 5 presents the spatial distribution of these fluxes for the corn growing seasons in 2010, inside the Bonança farm, Northwestern side of São Paulo state, Southeast Brazil. 
(a) Latent heat flux $-\lambda \mathrm{E}$
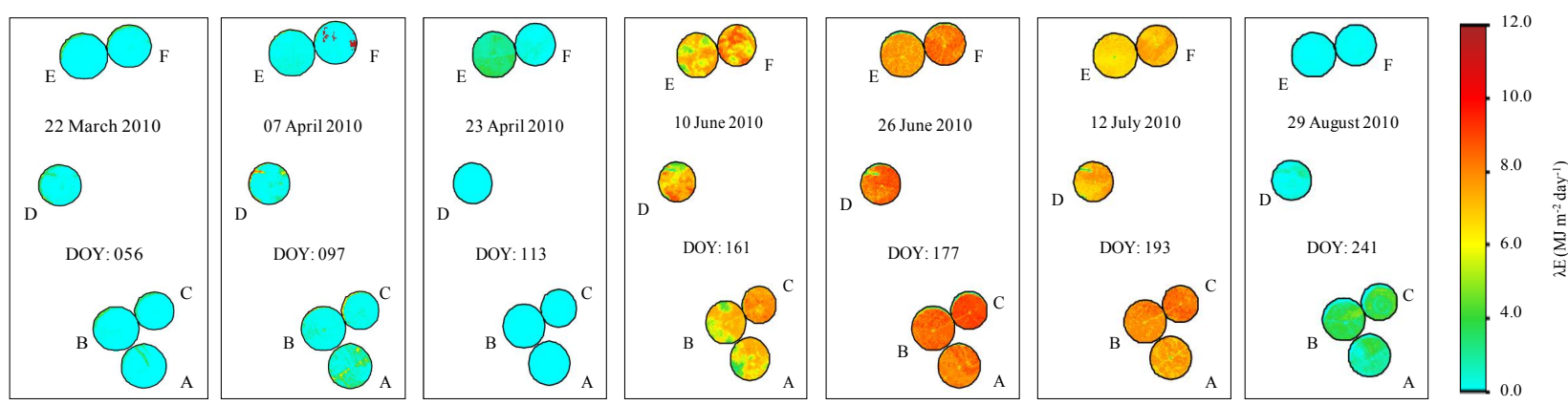

(b) Sensible heat flux - $\mathrm{H}$
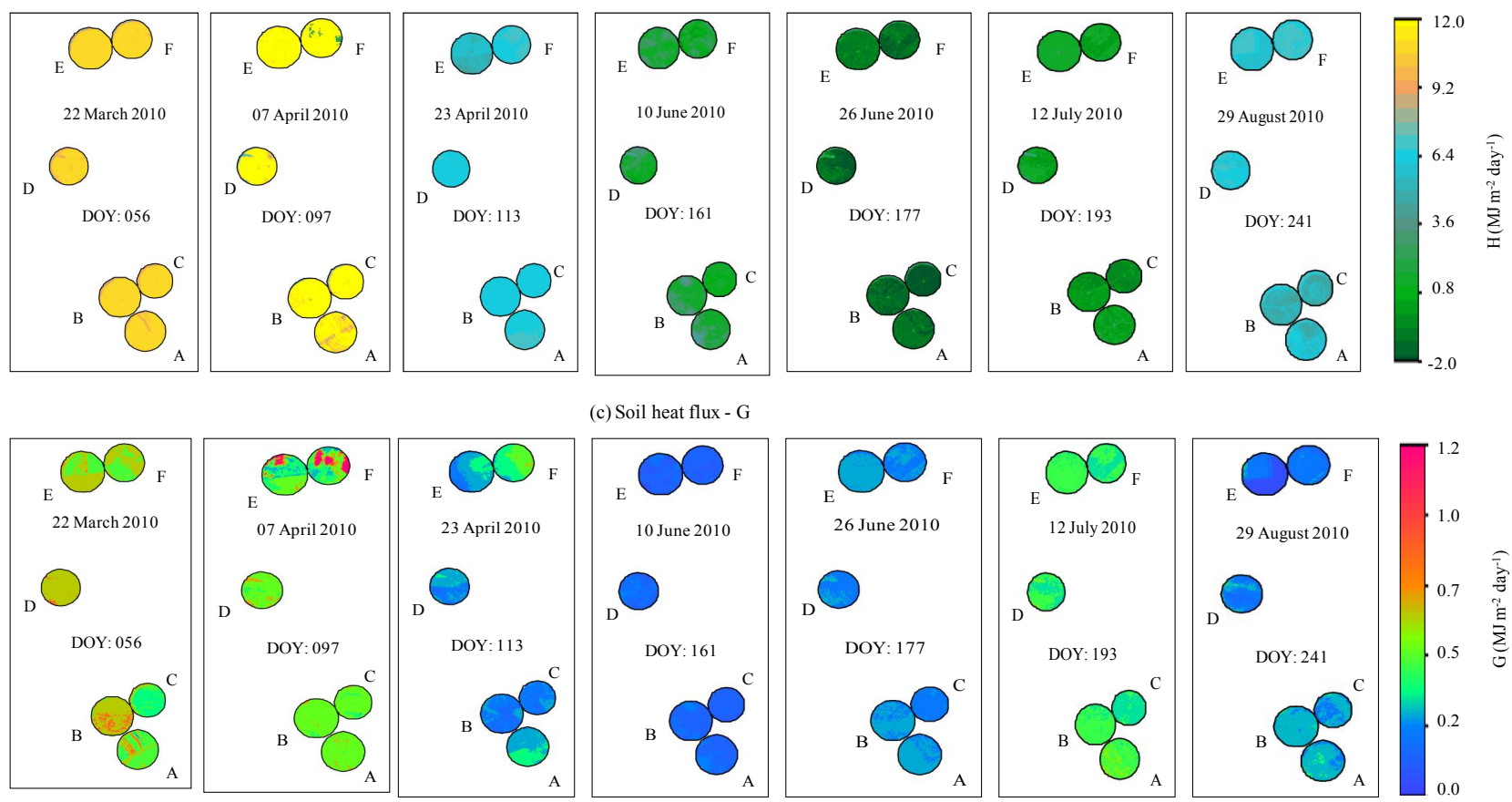

(c) Soil heat flux - G
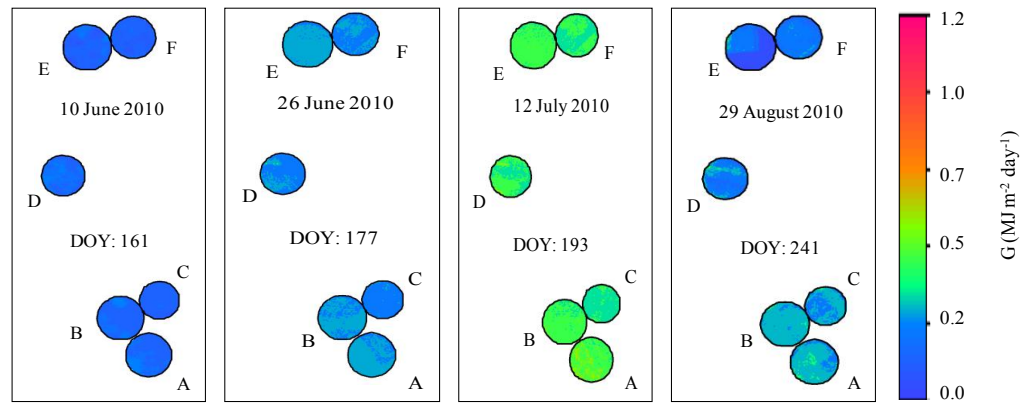

Figure 5. Spatial distribution of the daily values of the energy fluxes in the corn crop central pivots in Bonança farm, Northwestern side of São Paulo state, Southeast of Brazil, for each day of the year (DOY), involving different thermohydrological conditions along the growing seasons. (a) latent heat flux ( $\lambda \mathrm{E})$; (b) sensible heat flux $(\mathrm{H})$; and soil heat flux $(\mathrm{G})$.

Clearly one can distinguish the $\lambda \mathrm{E}$ pixel values according to the corn crop stages under the different thermohydrological conditions, with the highest values from DOY 161 to 193, corresponding to the lowest ones for $\mathrm{H}$. This time is the transition stage from blooming to grain filling, which happened during the coldest time of the year. The highest $\lambda \mathrm{E}$ values are for the pivots A, B and C in DOY 177-193. By the negative $H$ values and $\lambda E$ higher than $R_{n}$, horizontal heat advections from the vicinities of the irrigation pivots are verified. The lowest $\lambda \mathrm{E}$ and then the highest $\mathrm{H}$ occurred at the start of the growing seasons from DOY 056 to 113. Considering the G values, they followed the $\mathrm{H}$ behaviour, with the lowest ones in the middle of the year and the maximums from DOY 056 to DOY 097. By the G values and its spatial variation inside the pivots, it became evident that in the current study it is not reasonable to neglect this energy flux, as was done in the Brazilian semi-arid conditions [5].

Transforming $\lambda \mathrm{E}$ into $\mathrm{mm}$ of water, the highest $\mathrm{ET}$ rates were for the pivots $\mathrm{A}, \mathrm{B}$ and $\mathrm{C}$, with growing seasons (GS) totals above $450 \mathrm{~mm}$. Most of the daily ET values were in the range from 1.5 and $4.0 \mathrm{~mm}^{-1} \mathrm{yy}^{-1}$. In the Northwest of China, [13] throughout field measurements and modelling, found similar daily rates around $3.5 \mathrm{~mm} \mathrm{day}^{-1}$, what brings confidence of using the models in the current research with only the Landsat visible and infrared bands in irrigation pivots. 
As the irrigation pivots involved different sowing dates, and then all the corn crop stages under different thermohydrological conditions of 2010, the energy balance components were related to the accumulated degree-days for a general growing season in the Bonança farm, Northwestern side of São Paulo state, Southeast Brazil (Figure 6).

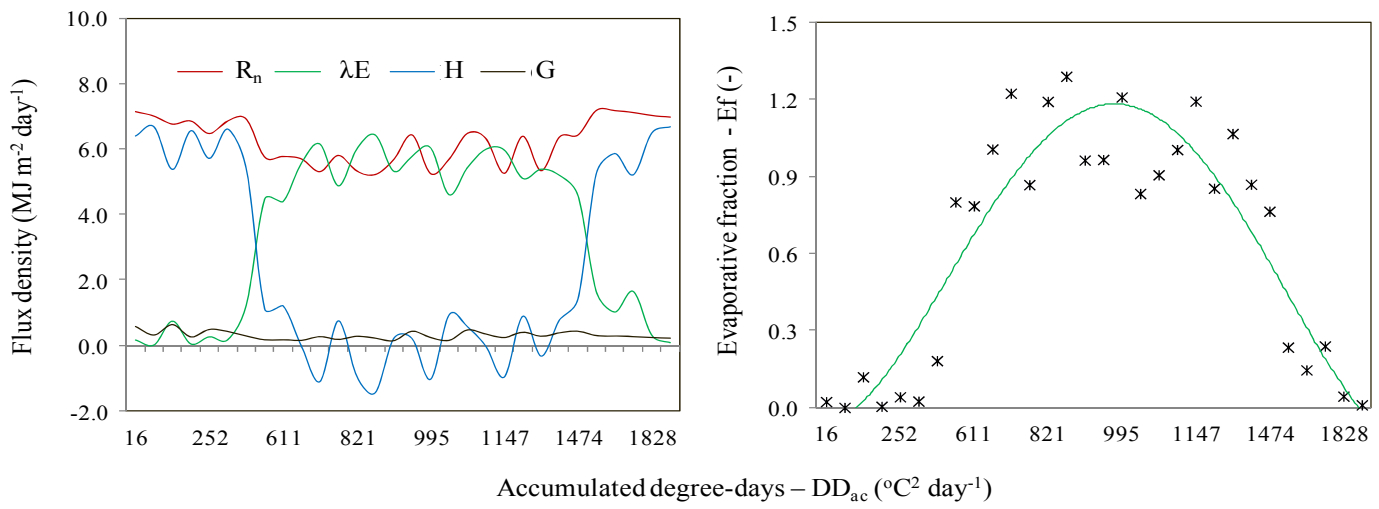

Figure 6. Variations of the mean values of the energy balance components with the accumulated degree-days $\left(\mathrm{DD}_{\mathrm{ac}}\right)$ in the corn irrigation pivots from the Bonança farm, Northwestern side of São Paulo state, Southeast Brazil: (a) net radiation $\left(\mathrm{R}_{\mathrm{n}}\right)$, latent heat flux $(\lambda \mathrm{E})$, sensible heat flux $(\mathrm{H})$ and soil heat flux $(\mathrm{G})$; (b) evaporative fraction $\left(\mathrm{E}_{\mathrm{f}}\right)$. A basal temperature of $10{ }^{\circ} \mathrm{C}$ was considered for $\mathrm{DD}_{\mathrm{ac}}$.

According to Figures 2 and $6 \mathrm{a}$, the mean $\mathrm{R}_{\mathrm{n}}$ values were between 5.2 and $7.2 \mathrm{MJ} \mathrm{m}^{-2}$ day $^{-1}$, following the $\mathrm{R}_{\mathrm{G}}$ levels. The fractions of $R_{G}$ transformed into $R_{n}$ ranged from 0.34 in the image of 22 March 2010 to 0.45 for DOY 056 and 097 (March and April). Field measurements retrieved $\mathrm{R}_{\mathrm{n}}$ averaged values being $46 \%$ of $\mathrm{R}_{\mathrm{G}}$ for wine grape, $55 \%$ for table grape, $51 \%$ for mango orchard, and $53 \%$ for natural vegetation in the Brazilian semiarid conditions [8]. The current results are also in agreement with studies involving other agro-ecosystems [13-15], what give confidence of the remote sensing methods for the radiation balance. The lowest average $\lambda \mathrm{E}$ values, close to zero happened at the start and harvest stages of the growing seasons, while the highest ones occurred when $\mathrm{DD}_{\mathrm{ac}}$ were between 650 and $1450{ }^{\circ} \mathrm{C}$ day ${ }^{-1}$, involving the blooming and grain-filling stages. $\mathrm{H}$ showed an inverse behaviour of that for $\lambda \mathrm{E}$, with some negative mean values indicating several cases of horizontal heat advection. Although $\mathrm{G}$ being the lowest energy flux, its average range was between 0.1 and $0.6 \mathrm{MJ} \mathrm{m}^{-2}$ day $^{-1}$, with the highest values at the start of the growing seasons. The fractions of $\mathrm{R}_{\mathrm{n}}$ used as $\lambda \mathrm{E}, \mathrm{H}$ and $\mathrm{G}$ ranged respectively from 0.00 to $1.20,-0.30$ to 0.97 , and 0.02 to 0.07 . This sensibility reinforces the confidence of the model applications with only the red and infra red bands of Landsat images at the spatial scale of $30 \mathrm{~m}$ for irrigation pivots.

The evaporative fraction $\left(\mathrm{E}_{\mathrm{f}}\right)$ is a measurement of the soil moisture conditions, and as the water deficit may limit corn crop yield [2,3], its trend was also quantified throughout a generalized growing season, as a function of $\mathrm{DD}_{\mathrm{ac}}$ (Figure $6 \mathrm{~b}$ ). It can be concluded that in the most of the water use critical periods during the corn crop stages, between $\mathrm{DD}_{\mathrm{ac}}$ of 500 and $1500{ }^{\circ} \mathrm{C}_{\text {day }^{-1}}$, the $\mathrm{E}_{\mathrm{f}}$ values were above 0.75 , and even higher than 1.00 because of the additional energy supply by the horizontal heat advection. The polynomial trend depicted in Figure $6 \mathrm{~b}$ and the average $\mathrm{E}_{\mathrm{f}}$ of 0.63 for a growing season indicated a good irrigation management at the Bonança commercial farm, insuring that the water scarcity could not be the reason of any yield drop in 2010 .

\section{CONCLUSIONS}

The coupled use of remote sensing and agrometeorological stations allowed the quantification and analyses of the energy balance components at the irrigation pivots scale for a generalized corn crop growing season in a commercial farm of São Paulo state, Southeast Brazil. Net radiation is most strongly influenced by the solar radiation conditions than the soil moisture or the crop stages. It was demonstrated that the daily fluxes of latent, sensible and soil heat fluxes can be estimated from instantaneous measurements of the red and infra red radiation from the Landsat sensor, throughout the modelling of the ratio of the actual to reference evapotranspiration at the satellite overpass time. The mean fractions of 
the latent, sensible and soil heat fluxes to net radiation were respectively 56,39 and $5 \%$. In some occasions, inside the irrigated areas, it was evidenced heat fluxes coming from the natural dryer areas at the vicinities of irrigation pivots. The values of evaporative fraction indicated a good irrigation management, insuring that the water deficit could not be the reason of any yield drop. These energy balance analyses can contribute the monitoring of the corn crop water use, considering the rational use of the water resources.

\section{ACKNOWLEDGEMENTS}

The research herein was supported by the CNPq and the Brazilian Ministry of Agriculture, both acknowledged for the financial supports to the projects on Water Productivity in Brazil.

\section{REFERENCES}

[1] Ko, J., Piccinni, G. "Corn yield responses under crop evapotranspiration-based irrigation management," Agric. Water Manage. 96, 799-808 (2009).

[2] Traore, S.B., Carlson, R.E., Pilcher, C.D., Rice, M.E. "Bt and non-Bt maize growth and development as affected by temperature and drought stress," Agron. J. 92, 1027-1035 (2000).

[3] Payero, J.O., Melvin, S.R., Irmak, S., Tarkalson, D. "Yield response of corn to deficit irrigation in a semiarid climate," Agric. Water Manage. 84, 101-112 (2006).

[4] Hernandez. F.B.T., Souza. S.A.V. de, Zocoler. J.L., Frizzone. J.A. "Simulação e efeito de veranicos em culturas desenvolvidas na região de Palmeira d'Oeste. Estado de São Paulo,” Eng. Agric. 23, 21-30 (2003).

[5] Teixeira, A.H. de C., Hernandez, F.B.T., Lopes, H.L., Scherer-Warren, M., Bassoi, L.H. A Comparative Study of Techniques for Modeling the Spatiotemporal Distribution of Heat and Moisture Fluxes in Different Agroecosystems in Brazil. In: George G. Petropoulos. (Org.). Remote Sensing of Energy Fluxes and Soil Moisture Content. 1ed.Boca Raton, Florida: CRC Group, Taylor and Francis, 169-191 (2014).

[6] Santos. G.O., Hernandez. F.B.T., Rossetti. J.C. "Balanço hídrico como ferramenta ao planejamento agropecuário para a região de Marinópolis, noroeste do Estado de São Paulo,” Rev. Bras. Agric. Irrig. 4, 142-149 (2010).

[7] Teixeira, A.H. de C. Water productivity assessments from field to large scale: a case study in the Brazilian semi-arid region; LAP Lambert Academic Publishing: Saarbrücken, Germany, 226p. (2009).

[8] Teixeira, A. H. de C., Bastiaanssen, W. G. M., Ahmad, M. D., Bos, M. G. "Analysis of energy fluxes and vegetationatmosphere parameters in irrigated and natural ecosystems of semi-arid Brazil," J. Hydrol. 362, 110-127 (2008).

[9] Teixeira, A. H. de C. "Determining regional actual evapotranspiration of irrigated and natural vegetation in the São Francisco river basin (Brazil) using remote sensing an Penman-Monteith equation," Rem. Sens., 2, 1287-1319 (2010).

[10] Allen, R. G., Pereira, L. S., Raes, D.; Smith, M. Crop Evapotranspiration: Guidelines for Computing Crop Water Requirements; Food and Agriculture Organization of the United Nations: Rome, Italy (1998).

[11] van Dijk, A. I. J. M., Bruijnzeel, L. A., Schellekens, J. "Micrometeorology and water use of mixed crops in upland West Java, Indonesia," Agric. For. Meteorol. 124, 31-49 (2004).

[12] Li, S.-G., Eugster, W., Asanuma, J, Kotani, A., Davaa, G., Oyunbaatar, D., Sugita, M. "Energy partitioning and its biophysical controls above a grazing steppe in central Mongólia,” Agric. For. Meteorol. 137, 89-106 (2006).

[13] Hughes, C. E., Kalma, J. D., Binning, P., Willgoose, G. R., Vertzonis, M. "Estimating evapotranspiration for a temperate salt marsh Newcastle, Australia," Hydrol. Process. 15, 957-975 (2001).

[14] Yunusa, I.A.M., Walker, R.R., Lu, P. "Evapotranspiration components from energy balance, sapflow and microlysimetry techniques for an irrigated vineyard in inland Australia," Agric. For. Meteorol. 127, 93-107 (2004).

[15] Ding, R., Kang, S., LI, F., Zhang, Y., Tong, L. "Evapotranspiration measurement and estimation using modified Priestly-Taylor model in an irrigated maize field with mulching." Agric. For. Meteorol. 168, 140 -148 (2013). 